\title{
Linguodidactic potential of Microsoft Teams applications for teaching English vocabulary
}

\author{
Ekaterina Sergeevna Osipova* and Ekaterina Yuryevna Bagrova \\ Peter the Great St. Petersburg Polytechnic University, Foreign Language Department, \\ Saint-Petersburg, Russia
}

\begin{abstract}
The paper analyzes the existing research and case studies of using Microsoft 365 Teams (MS Teams) for educational purposes while teaching English as a Foreign Language (EFL) during distance learning in the midst of the Covid-19 pandemic and provides an introduction to the innovative use of MS Teams. The given article reveals some aspects of implementing Microsoft Teams applications (MS Teams apps) with a strong linguodidactic potential (Collaboard, WordClouds, Mindomo, Kahoot, Flipgrid, Quizlet, myQuiz, Fortune Cookie) in university students' vocabulary teaching. The authors underline the methodological value of the abovementioned MS Teams apps and give some examples of the linguodidactic use of MS Teams apps in their own EFL teaching practice. Data were collected following the methods of theoretical analysis, the educational experiment was conducted following the empirical methods. The study provides an algorithm for a new way of teaching vocabulary to EFL students during distance learning and indicates which MS Teams apps can be used in terms of the stage of teaching vocabulary, exercise type, and activity type. As a result, the most optimal combination of using MS Teams apps to teach vocabulary during distance learning has been revealed: Collaboard, Mindomo (preparation) + Quizlet, WordClouds (presentation) + myQuiz, Kahoot (practice) + Flipgrid, Fortune Cookie (production).

Keywords: COVID-19; Microsoft Teams; distance learning; teaching vocabulary
\end{abstract}

\section{Introduction}

The COVID-19 pandemic has brought a shutdown of educational institutes around the world. This situation has changed traditional learning media into learning with virtual digital media. One of the virtual digital media is a cloud app Microsoft Teams 365 that is intended for "various activities, both online classes, meetings, tests online, file storage and collaboration" [1].

Microsoft Teams (MS Teams) is an application used by a plethora of universities during distance learning in the midst of the Covid-19 pandemic, because it provides a good integrated teaching-learning space. The decision behind giving preference to MS Teams is

*Corresponding author: osipova_es@spbstu.ru 
done due to some reasons. The most common ones are (a) possibility to take live online classes for multiple students at a pre-scheduled time; (b) possibility to record videos for the students to view; (c) possibility to upload any type of file (power-points, word or pdf documents, and video lectures); (d) possibility to design quizzes and tests which can be automatically graded based on some pre-defined rubric; (e) possibility to provide both a multi-party video-conferencing facility and a real classroom like virtual learning environment [2-8].

Therefore, more and more researchers start sharing their experience of using MS Teams in their foreign language classes and focus on the question what MS Teams can offer educators in higher education institutions. Louis Martin and Dave Tapp share their experience of the use of MS Teams to teach the Language of Law, focusing on the assignment tab to facilitate PowerPoint presentations in group workshops, allocate required reading and grade formative assignments [9]. Ahmad Ridho Rojabi's research is aimed at exploring EFL students' perceptions of online learning via MS Teams and reveals that online learning via MS Teams increases students' motivation and leads to better and easier comprehension of the learning materials [10]. Thi Thanh Mai Tran shares a positive experience of using MS Teams while teaching English, considering MS Teams "an effective way to keep learning activities going on", but mentioning "some inconveniences with technological problems" [11].

It is getting clear that using Microsoft Teams in online learning received much positive feedback, but at the same time a few disadvantages such as "student feedback, social isolation, time management and self-motivation" [12] have also been mentioned.

Notwithstanding the existing research and case studies of using MS Teams for educational purposes, nothing has been said about the linguododactic potential of a wide range of MS Teams apps.

\section{$2 \quad$ Materials and methods}

\subsection{Participants}

A total number of 86 first year EFL students from Peter the Great St. Petersburg Polytechnic University majoring in Electrical Engineering participated in the study in the year 2021. The average level of English is Intermediate (B2).

\subsection{Procedure}

The conducted research lasted one month and comprised two steps.

1) Educational experiment is targeted at teaching vocabulary on the topic "Advertising" in the form of distance learning via MS Teams apps (experimental group) and in the form of classroom learning (control group).

2) Control experiment is needed to check the effectiveness of the devised algorithm and compare the level of topic-related vocabulary knowledge of students in the control and the experimental groups.

Control experiment comprises (a) vocabulary test, which includes 30 questions based on the topic "Advertising", containing different types of non-communicative and semi-communicative exercises (the number of correct answers is assessed, at least 18 points for pass), (b) speaking task, a 2-minutes monologue on the topic "Advertising" (the number 
of correct use of topic-related vocabulary is assessed, at least 15 words or collocations for pass). Here is the example of a speaking task.

Describe an advertisement that persuaded you to buy a product. You should say (a) what it was (b) where it was shown (c) what was good about it (d) explain why the advertisement attracted you.

\subsection{Methods}

For the solution of the research tasks a series of methods were applied: a) methods of a theoretical analysis (analysis, synthesis, generalization, modeling, comparative); b) empirical methods (a set of experiments: educational and control); c) a tabular and graphical presentation of information.

\subsection{Materials}

For teaching vocabulary, we have chosen the MS Teams apps with the strongest linguodidactic potential.

Methodological value of Collaboard is presented by the golden opportunity to arrange brainstorming, mind-mapping, storytelling sessions on-line and organize an effective work with videos, which can be recorded directly from the whiteboard or uploaded from YouTube.

Wordclouds.com is a word cloud generator that helps paste text, upload a document or open an URL to generate a word or tag cloud automatically. The app can be used as a visual representation of the list of categories, keywords, or thematic word lists.

Mindomo is an app to create mind maps. Creating mind maps facilitates the understanding process and is considered a beneficial habit used in the learning and teaching processes.

The Kahoot is a game-based learning platform, the methodological value of the app is the possibility to create a variety of tests, multiple-choice quizzes, surveys or games.

Flipgrid allows teachers to create "grids" to facilitate video discussions. The methodological value is the opportunity to develop students' communication skills by creating full-fledged discussion on a given topic of the lesson.

Quizlet includes flashcards, study, and game modes, which is rather helpful for vocabulary work.

The methodological value of MyQuiz is the possibility to create any set of questions including video and image questions.

Fortune Cookies is an app with plenty of advice, recommendations and phrases about different spheres of life. The methodological value of Fortune Cookies is the opportunity to work with topic-related quotes and sayings.

\section{$3 \quad$ Results}

\subsection{The results of the educational experiment}

Having examined the linguodidactic potential of the abovementioned apps, we devised an algorithm of their use to teach vocabulary to EFL students according to (a) the stage of teaching vocabulary, (b) exercise type, (c) activity type. The results are presented in Table 1. 
Table 1. The algorithm of MS Teams app usage to teach vocabulary.

\begin{tabular}{|c|c|c|c|}
\hline $\begin{array}{l}\text { Stage of teaching } \\
\text { vocabulary }\end{array}$ & Exercise type & Activity type & $\begin{array}{c}\text { Relevant MS Teams } \\
\text { app }\end{array}$ \\
\hline $\begin{array}{l}\text { Pre-teaching stage } \\
\text { (to check students' } \\
\text { vocabulary background } \\
\text { on the topic) }\end{array}$ & & $\begin{array}{l}\text { - brainstorming } \\
\text { - mind-mapping }\end{array}$ & $\begin{array}{l}\text { Collaboard } \\
\text { Mindomo }\end{array}$ \\
\hline $\begin{array}{l}\text { Presentation } \\
\text { of a new vocabulary } \\
\text { item and its meaning }+ \\
\text { checking } \\
\text { comprehension }\end{array}$ & $\begin{array}{c}\text { non-communicative } \\
\text { / receptive }\end{array}$ & $\begin{array}{l}\text { - visual presentation } \\
\text { with the help of objects, } \\
\text { pictures } \\
\text { - supplying antonyms } \\
\text { and synonyms } \\
\text { - supplying definition } \\
\text { - matching } \\
\text { - grouping }\end{array}$ & $\begin{array}{c}\text { Quizlet } \\
\text { WordClouds }\end{array}$ \\
\hline $\begin{array}{l}\text { Practice } \\
\text { (tentative use of newly } \\
\text { introduced vocabulary) }\end{array}$ & $\begin{array}{l}\text { semi-communicativ } \\
\text { e/reproductive }\end{array}$ & $\begin{array}{l}\text { - multiple choice } \\
\text { - collocation grid } \\
\text { - gap filling, } \\
\text { - sentence completion } \\
\text { - paraphrasing }\end{array}$ & $\begin{array}{l}\text { myQuiz } \\
\text { Kahoot }\end{array}$ \\
\hline $\begin{array}{l}\text { Production } \\
\text { (communicative } \\
\text { practice, active use of } \\
\text { vocabulary through } \\
\text { creative activities) }\end{array}$ & $\begin{array}{l}\text { communicative / } \\
\text { productive }\end{array}$ & $\begin{array}{l}\text { - making dialogues } \\
\text { - story telling } \\
\text { - describing pictures } \\
\text { - recording video } \\
\text { - commenting video } \\
\text { - interpreting the } \\
\text { meaning of sayings, } \\
\text { quotes }\end{array}$ & $\begin{array}{c}\text { Flipgrid } \\
\text { Fortune Cookie }\end{array}$ \\
\hline
\end{tabular}

As a result of experienced distance learning in pandemic time, we have identified the combination of MS Teams apps to teach vocabulary: Collaboard, Mindomo + Quizlet, WordClouds (presentation) + myQuiz, Kahoot (practice) + Flipgrid, Fortune Cookie (production), which can be presented schematically in Figure 1.

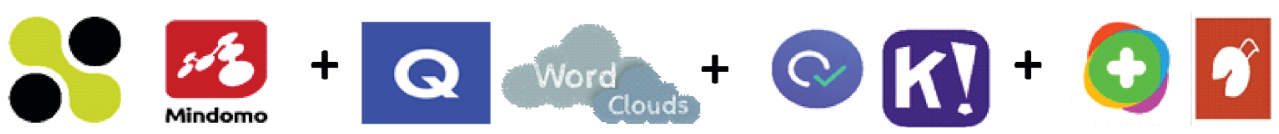

Fig. 1. The combination of MS Teams apps for teaching vocabulary.

In Table 2 there are some examples of the work with the abovementioned algorithm while teaching vocabulary on the topic "Advertising".

Table 2. The algorithm of MS Teams app usage to teach vocabulary.

\begin{tabular}{|l|l|l|}
\hline App and Stage & Exercise & Screenshots and Notes \\
\hline
\end{tabular}




\begin{tabular}{|c|c|c|}
\hline $\begin{array}{l}\text { Collaboard } \\
\text { (pre-teaching } \\
\text { stage) }\end{array}$ & $\begin{array}{l}\text { In } 7 \text { minutes } \\
\text { find and share } \\
\text { the following } \\
\text { information } \\
\text { on the topic } \\
\text { "What is } \\
\text { advertising?" } \\
\text { Group 1 - } \\
\text { stickers with } \\
\text { your ideas. } \\
\text { Group } 2- \\
\text { videos from } \\
\text { YouTube. } \\
\text { Group } 3- \\
\text { photos with } \\
\text { ads, logos, } \\
\text { slogans tc. } \\
\text { Group } 4- \\
\text { topic-related } \\
\text { texts. }\end{array}$ & 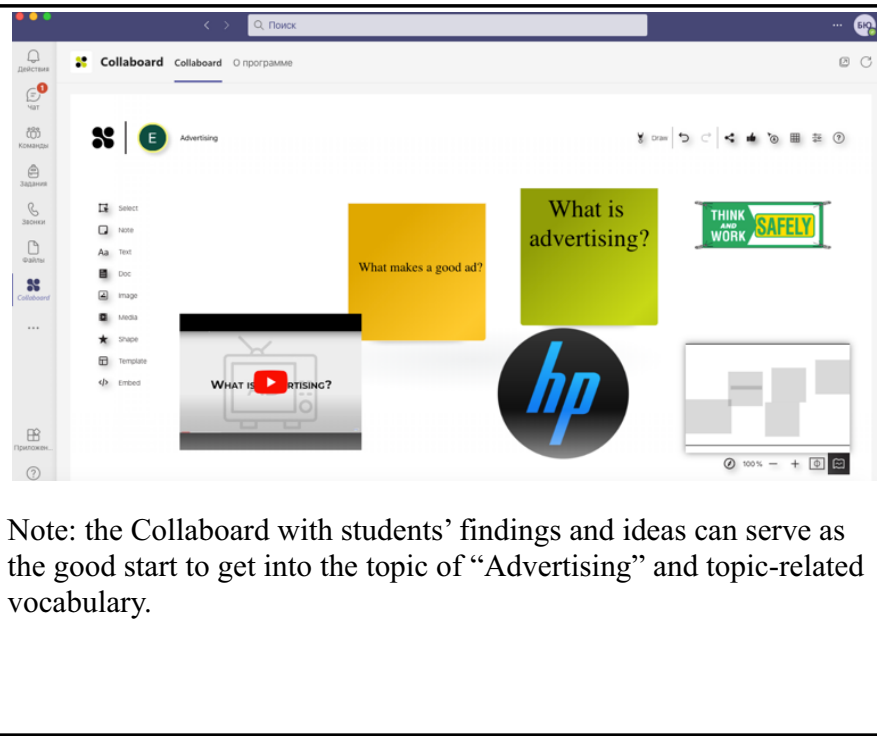 \\
\hline $\begin{array}{l}\text { Quizlet } \\
\text { (presentation) }\end{array}$ & $\begin{array}{l}\text { Work } \\
\text { individually } \\
\text { with Quizlet } \\
\text { following the } \\
\text { steps: cards, } \\
\text { memorization, } \\
\text { writing, } \\
\text { spelling } \\
\text { within one } \\
\text { lexical list. } \\
\text { In } 15 \text { minutes } \\
\text { be prepared } \\
\text { for a short } \\
\text { revision and } \\
\text { test. }\end{array}$ & 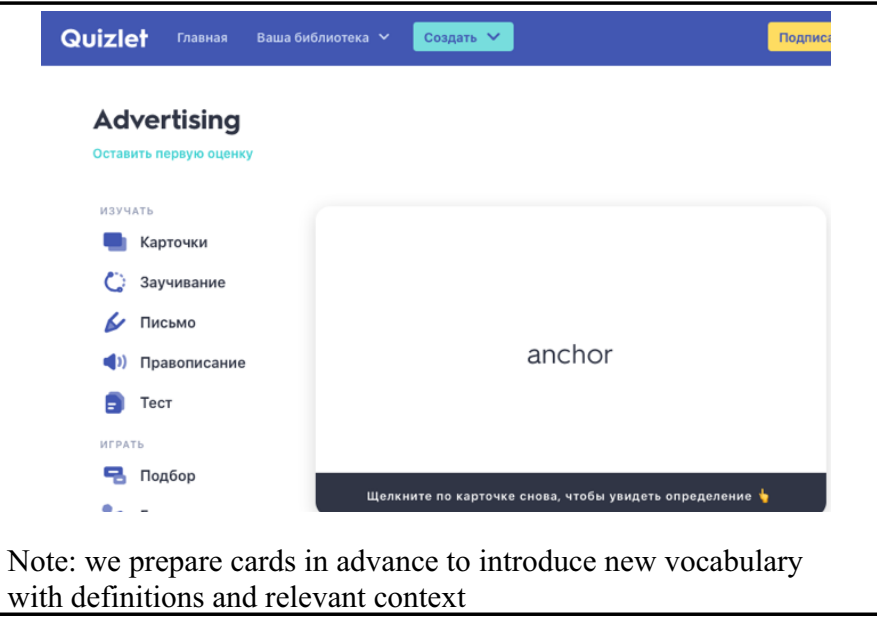 \\
\hline $\begin{array}{l}\text { Kahoot } \\
\text { (practice) }\end{array}$ & $\begin{array}{ll}\text { Play } & \text { a } \\
\text { vocabulary } & \\
\text { game } & \end{array}$ & 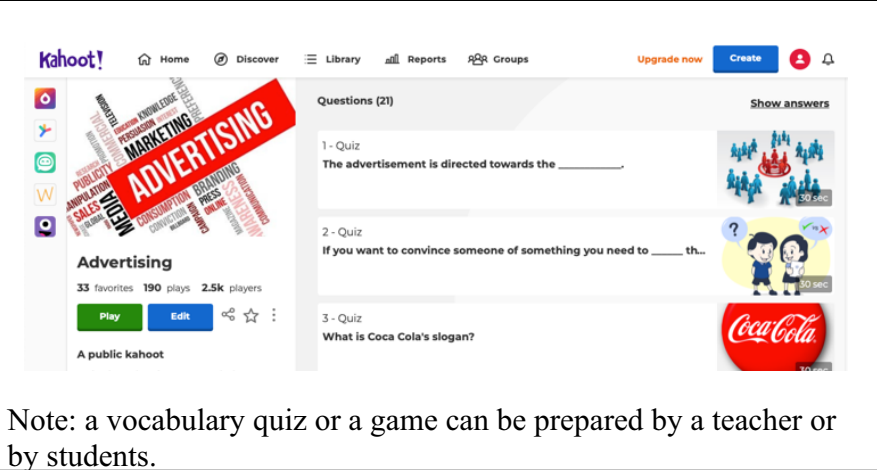 \\
\hline
\end{tabular}




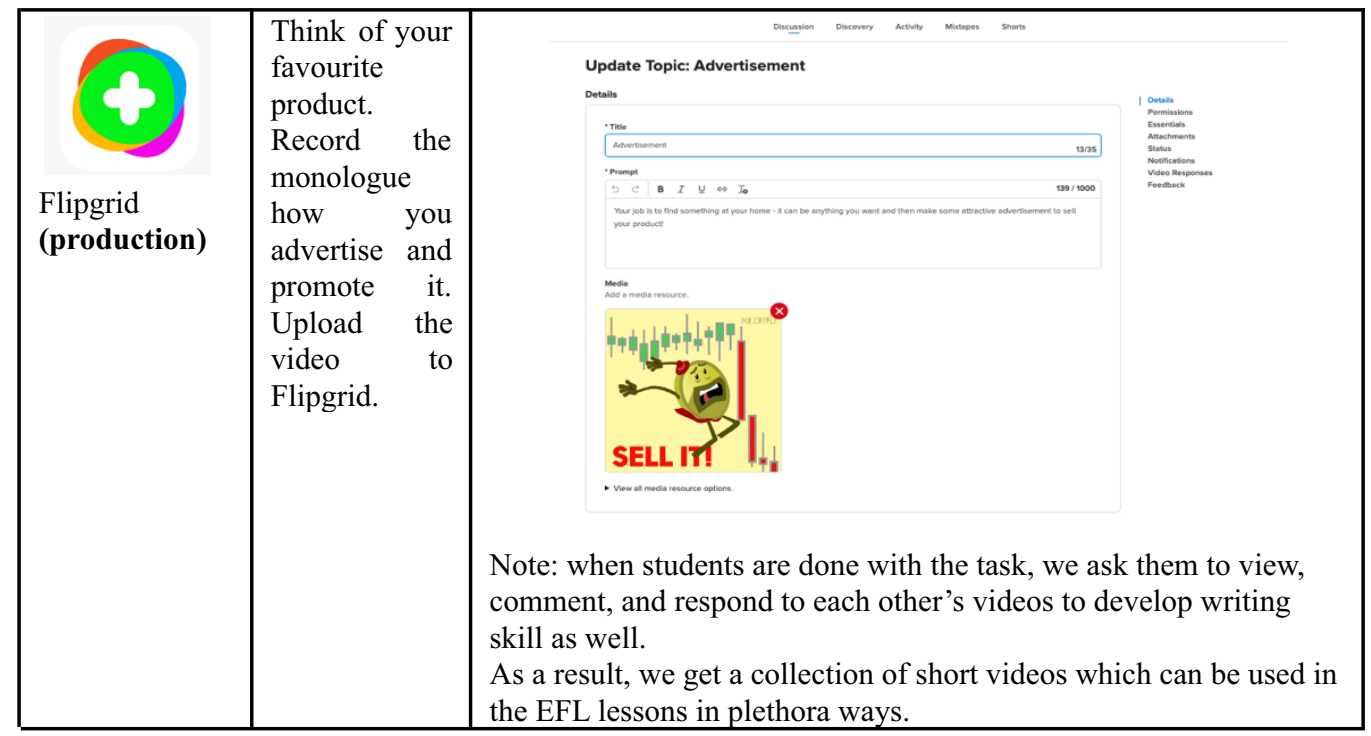

\subsection{The results of the control experiment}

The results of the level of topic-related vocabulary knowledge of students in the control group (classroom learning) and the experimental group (distance learning) are presented in the graph below (Figure 2), which illustrates that $65 \%$ of students in the control group and $85 \%$ in the experimental group managed to get 18 points out of $30(60 \%)$ and passed vocabulary test. In speaking tests there is not a big difference in the students' results, because speaking is not only about the number of topic-related vocabulary, coherence, cohesion, grammar accuracy, linkers play a vital role as well. Nevertheless, slightly more students from the experimental group managed to use at least 15 key words and collocations accurately in two minutes talk.

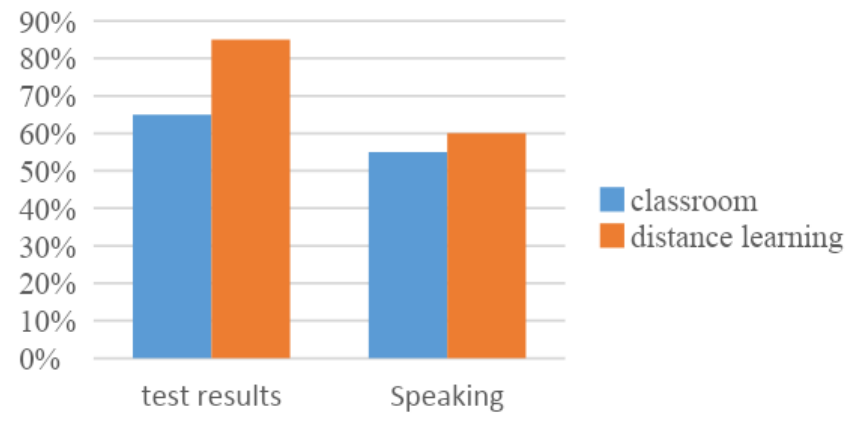

Fig. 2. The results of the level of topic-related vocabulary knowledge.

Therefore, we can conclude that the devised algorithm helps to boost the vocabulary as students showed better results in both aspects.

\section{Discussion}

Vocabulary teaching has always been a relevant topic under the consideration of many researchers, who offer different modern technologies to optimize this process: (a) mobile 
technologies [13, 14], (b) program Adelex [15], (c) story-sequencing task as a form of CMC (Computer-Mediated Communication) [16], (d) corpus technologies [17], social media sites [18], etc.

With the outbreak of COVID-19 pandemic, universities face the challenge of requiring new approaches in EFL teaching, most educational institutes supported MS Teams in online learning as an effective solution for teaching and learning in the complicated situation of pandemic. That is why we focused our attention on this media and started studying the linguodidactic potential of MS Teams, focusing on a wide range of its apps and their methodological value.

\section{Conclusion}

Summing up, Microsoft Teams is considered as an innovative online learning platform which provides unique features to help educators to conduct better interaction and create comfortable learning environment while teaching online. Interestingly, the results reveal that it is not a big deal to find an app to solve a single methodological task, but it is much more complicated to create a combination or a kind of chain of apps which can work comprehensively to follow our traditional steps in teaching this or that aspect of foreign language. The accumulated experience of teaching students via MS Teams apps can be transferred to the classroom or used in the development of distance courses.

\section{References}

1. Y.R. Wijayanto, A. Andayani, S. Sumarwati, Int J Multicult Multirelig Underst, 8(2), 87-93 (2021). https://doi.org/10.18415/ijmmu.v8i2.2333

2. R. Buchal, E. Songsore, Using Microsoft Teams to support collaborative knowledge building in the context of sustainability assessment, in Proceedings of the Canadian Engineering Education Association (CEEA) (2019). https://doi.org/10.24908/pceea.vi0.13882

3. D. Henderson, et al., Future Healthcare J, 7(3), e67 (2020). https://doi.org/10.7861/fhj.2020-0071

4. M. Hubbard, M.J. Bailey, Mastering Microsoft Teams (Apress, Berkeley, 2018). https://doi.org/10.1007/978-1-4842-3670-3

5. B.N. Ilag, Organization Readiness for Microsoft Teams, in Understanding Microsoft Teams Administration, 231-262 (Apress, Berkeley, 2020). https://doi.org/10.1007/978-1-4842-5875-0_3

6. M. McVey, A. Edmond, D. Montgomery, Supporting Students to Develop their Digital Literacies using Microsoft Teams, in ALT Winter Conference 2019, 11-12 Dec (2019). http://eprints.gla.ac.uk/206468/

7. D. Pal, V. Vanijja, Child Youth Serv Rev, 119, 105535 (2020). https://doi.org/10.1016/j.childyouth.2020.105535

8. N.T.T. Thai, B. De Wever, M. Valcke, J Comp Assist Learn, 36(3), 397-411 (2020). https://doi.org/10.1111/jcal.12423

9. L. Martin, D. Tapp, Innov Prac Higher Edu, 3(3), 58-65 (2019)

10. A.R. Rojabi, Engl Lang Teach Edu J, 3(2), 163-173 (2020). https://doi.org/10.12928/eltej.v3i2.2349 
11. M.T.T. Tran, AsiaCALL, 12(2), 12-23 (2021)

12. S. Ismail, S. Ismail, J Phys: Conf Ser 1874, 012020 (2021). https://doi.org/10.1088/1742-6596/1874/1/012020

13. M. Makoe, T. Shandu, Int Rev Res Open Distrib Learn, 19(4) (2018). https://doi.org/10.19173/irrodl.v19i4.3746

14. R.K.Agca, S. Özdemir, Proc-Soc Behav Sci, 83, 781-785 (2013)

15. C.P. Basanta, A second-generation CALL vocabulary-learning program ADELEX: in search of a psychopedagogic model, in Insights into non-native vocabulary teaching and learning, 175-185 (Multilingual Matters, 2010).

https://doi.org/10.21832/9781847692900-013

16. E. Moladoust, Iran EFL J, 9(1), 134-143 (2013)

17. A.F. Mukhamadiarova, M.A. Kulkova, E.V. Firsova, Astra Salvensis, S1, 327-334 (2017)

18. S. Monica-Ariana, P. Anamaria-Mirabela, Annals Univ Oradea, Econ Sci Ser, 23(2), 120-130 (2014) 